\title{
Energy Consumption of European and African Shrews
}

\author{
Peter VOGEL
}

Vogel P., 1976: Energy consumption of European and African shrews. Acta theriol., 21, 13: 195-206 [With 1 Table \& 2 Figs.]

Is the extremely high oxygen consumption of shrews due to an unusually high basal metabolism? In an attempt to answer this longstanding question, we have measured the oxygen consumption of 13 species of shrews of different origin: from Europe - Sorex araneus, S. minutus, Neomys fodiens, Crocidura russula, and Suncus etruscus; from Africa - Crocidura bottegi, C. bicolor, C. jouvenetae, C. poensis, C. theresae, C. wimmeri, C. flavescens, and C. giffardi. The measurements, taken over a period of 20-30 minutes, were made in small, closedsystem chambers at $25^{\circ} \mathrm{C}$. The metabolic rat of our shrews of the subfamily Soricinae lies between the mean and minimum values of the Soricini $\left(M=126.2 W^{0.52} \mathrm{cal} / \mathrm{h}\right.$ and $M=82.6 W^{0.53} \mathrm{cal} / \mathrm{h}$, respectively), as recorded in the literature. The average for the African Crocidurinae is much lower $\left(M=43.6 W^{0.67}\right)$. The metabolic rate of the European Crocidura russula agrees with that of the African species. Thus, the Crocidurinae are characterized by a relatively low metabolic rate; the Soricinae, and in particular the tribe of the Soricini, by an extremely high metabolic rate. The tribes Neomyini and Blarinini occupy an intermediate position. These differences are also to be found at the level of the basal metabolism. This main difference between the two subfamilies can most likely be explained by evolution in geographical isolation under differential climatic conditions: the Crocidurinae having evolved in tropical Africa and the Soricinae in temperate Eurasia. [Centre Suisse de Recherches Scientifiques en Côte d'Ivoire (CSRS) and Institut de zoologie et d'ecologie animale, 19, place du Tunnel, CH-1005 Lausanne, Switzerland].

\section{INTRODUCTION}

The conspicious voracity of shrews, which suggests a special type of metabolism, has already been described by B rehm (1868). Morrison \& Pearson (1946) conducted the first respirometric measurements and demonstrated an energy consumption far above that of rodents having a comparable body size. The authors thus postulated that the Soricidae might assume a special physiological status among the mammals (P e a r s on, 1948). Since that time, numerous contributions to the subject have appeared, mainly from the USA, England and Poland (- detailed literature register in G ę b c z y ńs ki, 1965, 1971). Although

* This work was supported by grant 3.515 .71 and 3.821 .72 from the Schweizerischer Nationalfonds zur Förderung der wissenschaftlichen Forschung.

[195] 
the results in these latter publications are basically the same and the relatively high values were consistantly confirmed, the respective interpretations are diametrically opposed to each other.

Crucial is the question whether the basal metabolism $\left(M_{b}\right)$ of shrews corresponds to that of the other warm-blooded organisms - which is calculated according to the formula of $\mathrm{Kleiber}$ (1967) $M_{b}=3 W^{0.75}$ (heat production $M_{b}$ per hour in kcal; body weight $W$ in $\mathrm{kg}$ ). The basic difficulty lies in the fact that direct measurements of basal metabolism in shrews cannot be made because the requisite conditions of postabsorptive state and tranquil behaviour are mutually exclusive. A shrew with an empty stomach seeks food in an extremely active manner, for without nourishment death rapidly ensues.

Thus, in order to calculate the basal metabolism, the gross results of respiratory measurements must be corrected - whereby the specifically dynamic action of the protein-rich food must be taken into consideration. While Morrison, Ryser \& Dawe (1959), by means of their corrections, arrived at completely normal basal metabolism values accepted by other authors ( $\mathrm{Hawkins}$, J e well \& $\mathrm{T}$ omlinson, 1960; Buckner, 1964), Gębczyński (1965, 1971) points to the questionable nature of these corrections, and adheres to the contention that the Soricidae represent a special situation.

A new aspect of this situation was revealed by the work of Dryden et al. (1969) concerning the thyroid activity of the Indian house shrew Suncus murinus. These results show a totally normal energy metabolism, comparable to that of rodents, which might be due to the conditions of laboratory confinement, but more probably results from the tropical origin of the experimental animals. The latter explanation is supported by the investigation of $\mathrm{Hunkeler} \& \mathrm{Hunkeler}$ (1970). These authors examined the food consumption of 4 species of African shrews, which turned out to be considerably less than that of European and American shrews.

The capture and breeding of European shrews between 1965 - 1969 at the Institute of Zoology in Basel enabled me to make observations which suggest a greater complexity in this problem. A comparison of the native common shrew (Sorex araneus) with the almost equally heavy common European white-toothed shrew (Crocidura russula) of the same geographic origin revealed marked differences respecting survival time in traps, food consumption, and potential life span - all suggestive of a differential energy consumption (Vogel, 1972). As all the high consumption measurements (with one insignificant exception) were recorded with representatives of the red-toothed shrews, I am led to suspect differences at the level of the two subfamilies. The Soricinae 
would then be characterized by an elevated, the Crocidurinae possibly by a relatively "normal " level of metabolism.

A three-year stay at the "Centre Suisse de Recherches Scientifiques" (CSRS) in the Ivory Coast enabled me to become familiar with those species which Hunkeler \& Hunkeler (1970) had already examined respecting food consumption. During a subsequent stay in Europe, it was then possible to compare the oxygen consumption of European representatives with that of several African shrews.

\section{MATERIAL AND METHODS}

In June 1972, 13 representatives of 7 African species ${ }^{1}$ were available for respirometric measurements: from Upper Volta 2 Crocidura giffardi de Winton, 1898 (Nobéré $11^{\circ} 31^{\prime} \mathrm{N} / 1^{\circ} 13^{\prime} \mathrm{W}$ and Bobo-Dioulasso $11^{\circ} 13^{\prime} \mathrm{N} / 4^{\circ} 18^{\prime} \mathrm{W}$ ); from the Ivory Coast 1 Crocidura bicolor Bocage, 1889 (Ouango-Fitini $9^{\circ} 34^{\prime} \mathrm{N} / 4^{\circ} 1^{\prime} \mathrm{W}$ ), 1 Crocidura jouvenetae $\mathrm{He}$ im de $\mathrm{Bals}$ a c, 1958, 1 C. theresae $\mathrm{Heim}$ de $\mathrm{B}$ alsac, $1968,4 \mathrm{C}$. poensis (Frase r, 1843), 2 C. wimmeri $\mathrm{Heim}$ de Bal$\mathrm{s} a \mathrm{c} \& \mathrm{Aellen}, 1958$, and 2 C. flavescens (I. G e offroy, 1827), all originating in Adiopodoumé $5^{\circ} 20^{\prime} \mathrm{N} / 4^{\circ} 8^{\prime} \mathrm{W}$, near Abidjan. One Crocidura bottegi $\mathrm{T}$ ho $\mathrm{m}$ as, 1898, likewise from Adiopodoumé, was delayed and arrived in Bern for measurement at a later date.

For purposes of comparison, 4 species of Swiss origin were available: 4 Crocidura russula (Hermann, 1780), 1 Sorex araneus Linné, 1758 (juvenile), 2 Sorex minutus Linné, 1766 (juvenile), and 2 Neomys fodiens (Pennant, 1771).

For additional material, the original data obtained at an earlier time employing the same methods with Suncus etruscus (Weibel, Burri \& Cla as s en, 1971) were made available to me. This animal originated from the Basel captive colony (Vog e 1, 1970).

At the time the experiments began, all the shrews had been in captivity for at least a week and were thus accustomed to the new conditions.

A comparison of the literature reveals that respirometric measurements over 24 hours are preferable to short-time measurements. Nevertheless, because this type of measurement demands that the experimental animals be maintained under the most natural conditions possible, and because this precondition was not realizable at the time, we were compelled to conduct short-time measurements.

Oxygen consumption was measured in a closed system with automatic oxygen renewal; details can be found by Burri, Gehr, Mueller \& Weibel (1975). Before the measurements began, the animals were placed into the experimental cage for 10 minutes - which was usually sufficient for calming the animals down. The experiments lasted $20-30$ minutes. An observational protocol of animal activity served to facilitate critical evaluation of extreme results. With few exceptions, activity in the small cage is greatly reduced.

The experimental chamber was maintained at a temperature of $25^{\circ} \mathrm{C}$. by circulating water; for the European species, this lies surely in the zone of neutral temperature. For the African species, whose thermoneutral zone lies presumably

1 All nomenclature is according to $\mathrm{He}$ im de $\mathrm{B}$ a ls a c $(1966,1968)$ and $\mathrm{He}$ im cie Balsac \& Aellen (1958). 
$2-3^{\circ} \mathrm{C}$. higher, a small increase in metabolism due to thermoregulation cannot be excluded.

After taking the temperature and the barometric pressure into account, all values were recalculated to standard conditions $(S T P)$ and cal/h. For 1 liter of $\mathrm{O}_{2}$, 4.8 kcal were calculated ( $G$ ę b c z y ńs k i, 1965).

\section{RESULTS}

Figure 1 shows the number and position of the individual measurements. The intraspecific variation is clearly evident; this variation is, as might be expected, considerable - for all measured values were included, without further consideration of the observed animal activity. More important for our comparison than maximal or minimal values, however,

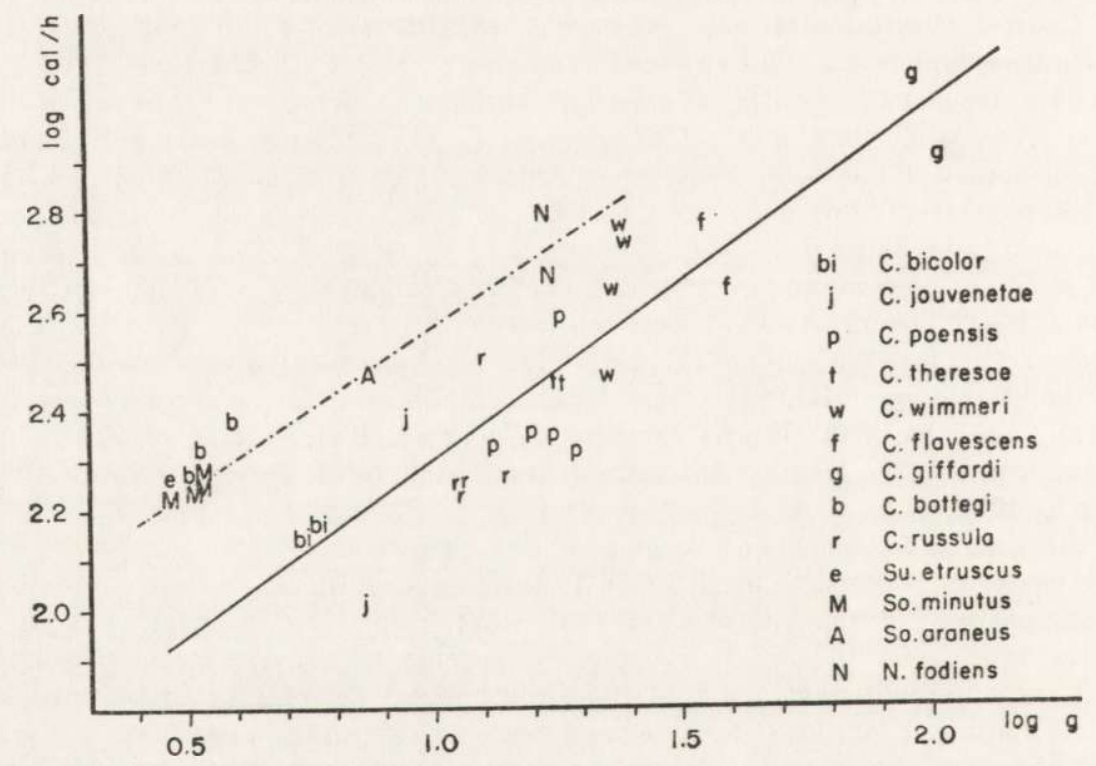

Fig. 1. Energy consumption of shrews: personal measurements, including the mean value for one Suncus etruscus (W e i b e l et al. 1971).

Small letters $=$ Crocidurinae (regression line $M=40.0 \mathrm{~W}^{0.69}$, without inclusion of $e, b$, and $r$ ). Large letters $=$ Soricinae (regression line $M=81.0 W^{0.65}$ ).

are the species-specific means (Table 1 and Fig. 2); these will be discussed in detail below.

In order to ascertain whether our method yields usable values, the results of the Soricinae (Sorex minutus, S. araneus, Neomys fodiens) will be compared to corresponding results of other authors. For this purpose, the most appropriate values are the means obtained by $\mathrm{Geq} b$ czyński $(1965,1971)$ and by Gębczyńska \& Gębczyński 
(1965) - which were obtained during 24-hour measurements with a large experimental group - supplemented with the reliable data of $\mathrm{Buck}$ n er (1964).

The means of Sorex and Microsorex vary around the regression line $\log M=2.10+0.52 \log W(M=$ total consumption in $\mathrm{cal} / \mathrm{h}, W=$ weight in g), with a correlation coefficient of $r=0.95$. Representatives of the genera Neomys and Blarina, on the other hand, lie clearly below this line; their metabolism is, in spite of their body weight, remarkably low. The exceptional situation of Blarina has been referred to by $\mathrm{M}$ a $\mathrm{r}$ tin s e $\mathrm{n}$ (1969).

The minimal values from Buckner (1964) and Pearson (1948) serve well as further points for comparison, and lie on a regression line parallel to that of the above-mentioned means: $\log M=1.92+0.53 \log$ $W$, with a correlation coefficient of $r=0.87$. Our Sorex measurements lie between the minimal and mean values of these authors. On the other hand, the average of Neomys fodiens lies too high - this being caused by the extreme activity of one single experimental animal. This possibility must further be taken into consideration by the evaluation of other extremely high values.

Respecting the tropical Crocidurinae, 6 of the 8 means of these African species lie beneath the minimal values of the Soricinae. With exclusion of the Crocidura bottegi, which completely deviates from the experimental series, the measurements vary about the regression line $\log M=1.64+$ $0.67 \log W$, with a correlation coefficient of $r=0.98$. Only one value, that for Crocidura wimmeri lies too high; nevertheless, this is accounted for as in the previous case of Neomys fodiens, i.e. by the extreme activity of the experimental animals. Only after a period of adjustment exceeding 30 minutes was one such animal sufficiently calmed down in the experimental chamber; thereafter his energy consumption decreased to the typical African rate ( - the lowest of the four values in Figure 1).

Our African Crocidura bottegi deviates in an unexpected manner from these otherwise homogenous results, lying in the midst of the higher values of the Soricinae. This is all the more surprising inasmuch as $\mathrm{Hunkeler} \& \mathrm{Hunkeler}$ (1970) had recorded a distinct difference in reference to their holarctic comparison species respecting food consumption. Still and all, these authors also pointed to a tendency toward increased food consumption, and related this to the extreme sensitivity of this species in captivity. $C$. bottegi also proved itself to be highly sensitive in our work - so that the possibility that an abnormal state existed in our single experimental animal can not be excluded. For this reason, I have omitted this species in the calculation of the regression line. 
The most decisive point in our comparison concerns the energy consumption of the European Crocidura russula. As Fig. 2 shows, the mean value of the 4 measured animals lies beneath the regression line of the

Table 1

Energy consumption of Soricidae according to various authors plus personal mean values.

$W=$ body weight, $g ; M=$ consumption per hour, cal/g; $M / W^{0.75}=$ consumption per metabolic body size.

\begin{tabular}{llllll}
\hline No. Species & $W$ & $M$ & $M / W$ & $M / W^{0.75} \quad$ Author \\
\hline
\end{tabular}

(a) Means SORICINI

\section{Sorex cinereus \\ Sorex articus}

Microsorex hoyi

Sorex araneus juv.

Sorex araneus ad.

Sorex minutus juv.

Sorex minutus ad.

NEOMYINI \& BLARININI

Blarina brevicauda

Cryptotis parva

Neomys anomalus

3.6253

253

$5.4 \quad 289$

$3.5 \quad 277$

$7.7 \quad 368$

11.6462

2.9207

$4.6 \quad 249$

70.4

53.5

79.4

47.5

$39.7 \quad 73.4$

$71.4 \quad 92.8$

$53.9 \quad 78.8$

$\begin{array}{llll}20.1 & 403 & 20.0 & 42.4\end{array}$

$5.7 \quad 342$

20.0

42.4

$31.5 \quad 60$.

$13.6 \quad 428$

30.3

Neomys fodiens juv.

$14.7 \quad 446$

$16.9 \quad 394$

23.3

59.3

47.2

(b) Minimum

SORICINI

Sorex cinereus

Sorex arcticus

Microsorex hoyi

Sorex cinereus

Sorex vagrans

Sorex trowbridgii

Sorex pacificus

(c) Personal means

CROCIDURINAE

Crocidura bicolor

Crocidura jouvenetae

Crocidura poensis

Crocidura theresae

Crocidura wimmeri

Crocidura flavescens

Crocidura giffardi

Crocidura bottegi

Crocidura russula

Suncus etruscus

SORICINAE

30 Sorex minutus

31 Sorex araneus

32 Neomys fodiens

$\begin{array}{rrrrl}3.6 & 129 & 35.8 & 49.3 & \text { Buckner, 1964 } \\ 5.4 & 195 & 36.2 & 55.0 & \text { Buckner, 1964 } \\ 3.5 & 187 & 53.5 & 71.3 & \text { Buckner, 1964 } \\ 3.5 & 176 & 50.4 & 68.7 & \text { Pearson, 1948 } \\ 5.0 & 190 & 38.1 & 56.8 & \text { Pearson, 1948 } \\ 6.7 & 231 & 34.5 & 55.5 & \text { Pearson, 1948 } \\ 10.4 & 289 & 27.8 & 49.8 & \text { Pearson, 1948 }\end{array}$

$\begin{array}{rrrrc}5.6 & 142 & 25.6 & 39.2 & \text { this publication } \\ 8.0 & 172 & 21.6 & 36.3 & " \\ 16.7 & 249 & 14.9 & 30.2 & " \\ 17.6 & 284 & 16.1 & 33.0 & " \\ 23.5 & 460 & 19.6 & 43.1 & " \\ 38.0 & 492 & 12.9 & 32.1 & " \\ 99.0 & 934 & 9.4 & 29.8 & " \\ 3.5 & 213 & 61.4 & 83.9 & " \\ 12.0 & 205 & 17.1 & 31.9 & " \\ 2.9 & 185 & 63.7 & 83.0 & " \\ & & & & , \\ 3.2 & 173 & 54.1 & 72.3 & , \\ 7.3 & 290 & 39.5 & 65.0 & , \\ 16.8 & 536 & 31.9 & 64.7 & ,\end{array}$

Buckner, 1964

Buckner, 1964

Buckner, 1964

Gębczyński, 1965

Gębczyński, 1965

Gębczyński, 1971

Gębczyński, 1971

Buckner, 1964

Pfeiffer \& Gass, 1961

Gębczyńska \& Gębczyński, 1965

Gębczyńska \& Gębczyński, 1965

Gębczyńska \& Gębczyński, 1965

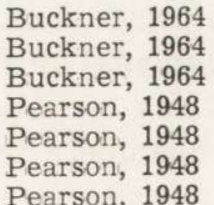

Pearson, 1948 
African species. As mentioned above though, we cannot exclude a small metabolic increase in the case of the African animals due to the experimental temperature. Hildwe in (1972), who was able to measure 3 Crocidura occidentalis in Gabun, did indeed obtain lower values than ours $^{2}$. In conclusion, the metabolism of European Crocidura coincides roughly with that of African Crocidurinae.

Most important of all is the indisputably large difference between the values of the European Crocidura russula in comparison to that of Sori-

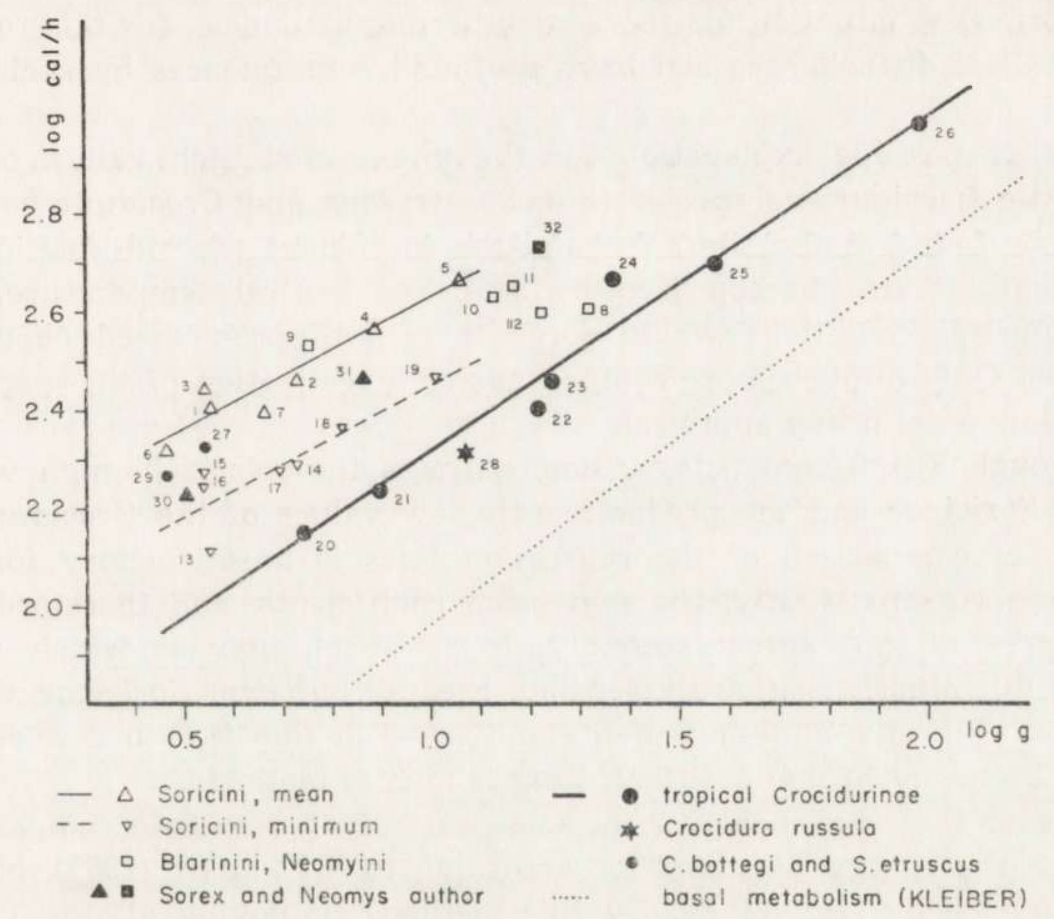

Fig. 2. Energy consumption of Soricinae and Crocidurinae: Graphic representation of Table 1.

Solid symbols=personal mean values. Regression lines: Mean values of Soricini $M=126 W^{0.52}$; Minimal values of Soricini $M=82.6 W^{0.53}$; Mean values of Crocidurinae $M=43.6 W^{0.67}$; Basal metabolism according to $\mathrm{Klei}$ be r $M_{b}=16.2 W^{0.75} \mathrm{cal} / \mathrm{h}$.

cinae, especially of Sorex araneus (of equal weight). Thus, these respirometric experiments confirm the concept of differential metabolic consumption as previously postulated on the basis of various indices ( $\mathrm{V}$ og e l, 1972).

2 After completion of this manuscript, Dryden, Gę bc zyński \& Douglas (1974) published measurements of oxygen consumption of the tropical Suncus murinus (Crocidurinae). The values for adult animals of a long-existing laboratory colony are also somewhat below the values of our African shrews. 
The surprisingly high mean value of our Suncus etruscus, which cannot be explained by either unusual activity or by an abnormal state, merits a special commentary. On the basis of the mediterranean distribution of this species, which has also been found south of the Sahara ( $\mathrm{H}$ e i m de Bals a c, 1958), one would theoretically expect a relatively low metabolism. Its ability to undergo reversible hypothermia (V o g e 1 , 1974), extraordinary for a member of the Soricidae, points in the same direction. Nevertheless, its average weight of $1.9 \mathrm{~g}$ places Suncus etruscus in a borderline situation for the homeothermic mammals; for this reason, the smallest disturbances can have profound consequences by such tiny shrews.

Another possible explanation for the unexpected high values of the two little Crocidurinae species (Suncus etruscus and Crocidura bottegi) might be found in the short fur and the inefficient thermo-isolation: If these species are characterized by a higher neutral temperature, our experimental conditions would force them into pronounced chemoregulation. Only a much more comprehensive investigation of these species will allow a definitive appraisal.

Although Fig. 2 convincingly demonstrates the relatively high values of the Soricinae and the predominantly low values of the Crocidurinae, the direct comparison of the regression lines is unsatisfactory for the following reasons: firstly, the regression coefficients, and therefore also the slopes do not agree; secondly, a statistical analysis which could clarify the situation is hardly sensible because our own Soricinae values are based on only 7 measurements and those in the literature were obtained by means of many different experimental methods.

In order to arrive, however, at some sort of approximate comparison, we base the energy consumption, according to $\mathrm{Kl}$ e i b e r (1967), on the "metabolic body size, $W^{0.75}$ «. By this method, employing all the values in Table 1, we arrive at a mean value of $69.1 \pm 3.8 \mathrm{cal} / \mathrm{h}$ for the Soricinae, and $44.2 \pm 6.6 \mathrm{cal} / \mathrm{h}$ for the Crocidurinae; the basal metabolism computed according to $\mathrm{Kl}$ e iber results in $16 \mathrm{cal} / \mathrm{h}$. Still and all, even this rough estimation demonstrates the difference between the two subfamilies. Inspite of the inclusion of several questionable values, the Student's $t-$ test yields a statistically highly significant difference $(P<0.5 \%)$.

\section{DISCUSSION}

Up until several years ago, there was general adherence to $\mathrm{Kle}$ ib e r's formula as the fundamental description of the basal metabolism of all homeotherms; deviating results were brought into agreement by means of corrective calculations. P o c zopko (1971) then demonstrated that at least 4 levels of metabolism can be differentiated: in progressive 
order the Metatheria, the Eutheria, the non-passerine birds and, at the summit, the Passeriformes (passerine birds). The same author also called attention to the disputed values for the small insectivores, (which surpass even those of the passerine birds), without nevertheless suggesting an appropriate classification.

A correct evaluation of the shrews has been hitherto impossible because previous investigations always compared them with rodents. Owing to the dissimilar nourishment and activity of these two animal groups, each set of results has been open to a wide variety of differential interpretations. Weighty physiological indices, such as tissue metabolism in vitro ( $\mathrm{Malzahn}, 1974)$ and hematological criteria ( $\mathrm{W} \circ \mathrm{k}, 1974$ ) though, support once again an exceptional position for the family of the Soricidae. Our oxygen consumption studies, performed under identical conditions on 13 representatives of this family demonstrate differences between the two subfamilies which cannot be explained in terms of the specifically dynamic action of the food, and therefore imply a differential basal metabolism.

Pearson's (1948) and Gębczyński's (1965) conception of an especially high metabolism in shrews is thus confirmed by our results. Nevertheless this conclusion is valid only for the subfamily of the Soricinae, leaving out the problematical value for Suncus etruscus. On the other hand, compared with the red-toothed shrews, the subfamily Crocidurinae is characterized by a relatively low metabolism. These fundamental differences within the same family were already suspected by Dehnel (1950), based on Tupikova's (1949) investigation of the nourishment and activity of East-European shrews (Crocidura suaveolens, among others).

As far as the hitherto published data on energy consumption permit a conclusion, the Soricinae can also be sub-divided into extreme and more moderate forms. Here we see a clear correlation with $\mathrm{R}$ e pen$\mathrm{n}$ ing's (1967) systematic classification into 3 tribes: the Soricini is characterized by the most extreme energy consumption; the Neomyini (e.g. Neomys) and the Blarinini (Blarina and Cryptotis) assume a more moderate position.

Finally, we must seek to unravel the meaning of these differences in basal metabolism. Contrary to the opinion of $\mathrm{S} \mathrm{ch}$ ol a n d e r (1955), who excluded the possibility of a climatic adaptation through alteration of the basal metabolism, Hild w e in (1972) demonstrated that animal groups typically native to the tropics (Hyracoidea, Pholidota, etc.) are characterized by a reduced basal metabolism. Nevo \& Shkolnik (1974) have recently discovered differences in basal metabolism even between different chromosome races of Spalax ehrenbergi which correlate with the 
respective mesoclimates. Thus, we arrive at an evolutionary explanation for certain differences in basal metabolism. When applied to our shrews, this explanation suffices for the low metabolism of the tropical Crocidurinae, but not for that of the Middle-European Crocidura species.

A possible solution, which at the present must remain a pure hypothesis, is forthcoming from the geographic distribution of the two contemporary subfamilies. The primary distribution area of the Soricinae is the holarctic region (excepting Mediterranean Africa), that of the Crocidurinae the palaeotropic region, nevertheless with a conspicuous tendency toward dissemination in Eurasian areas.

I consider it probable that from the ancestral Soricidae-stock, 2 groups became isolated under different climatic conditions: one, under tropical conditions in the Indo-African area, developed into the subfamily Crocidurinae; the other group, in a temperate climate, most likely Eurasia, evolved into the subfamily Soricinae. R e p e n n in g (1967), who likewise views a geographic isolation as the decisive factor in this subfamily development, places the separation in the Miocene Tethys seaway.

Due to secondary dissemination, the areas overlap in Eurasia. In Europe, the Crocidurinae are absent in the north as well as at higher altitudes, the Soricinae on the other hand in the low areas of the south. The area border of the sympatric zone of the subfamilies results thus from the combined effect of microclimate and energy consumption in interaction with the interspecific competition. In other words, by too cool a climate the Crocidurinae are no longer capable of competing, by too warm a climate, the Soricinae. Naturally, other factcrs, such as species-specific requirements, are also involved which cannot be discussed within the scope of this publication.

In the Americas, where competition from the originally tropicallyadapted Crocidurinae is absent, the Blarinini have apparently developed within the Soricinae; the genus Cryptotis, for instance, has penetrated southwards into the insectivore vaccuum of tropical Middle and South America. It is to be expected that these forms will also exhibit a secondarily climate-adapted lowered metabolism.

As a first step in the verification of this working $h_{1} y$ pothesis, the energy consumption and the ecological demands of European Crocidurinae should be examined on a wide basis.

Acknowledgements: I should like to express my gratitude to the Commission of the "Centre Suisse de Recherches Scientifiques ", most especially to Prof. J. G. B a e r (Neuchâtel), Prof. H. J. H uggel (Geneve), and Mr. E. W i m mer (Abidjan), who have always shown great interest in my work. In addition, my thanks are due to Prof. E. W e ibel (Bern) who kindly placed his apparatus at my disposal. To him, as well as to PD Dr. P. B urri, Dr. P. Gehr, Miss. H. Cla a s s en, and Mr. K. $\mathrm{Babl}$ (Bern), who solved many of the technical problems. I wish to acknowledge 
my indebtedness; also, to Dr. A. Meylan (Nyon), who provided me with indigenous shrews.

\section{REFERENCES}

1. Brehm A. E., 1868: La vie des animaux. Edition française, Baillière, Paris.

2. Buckner C. H., 1964: Metabolism, food capacity and feeding behaviour in four species of shrews. Can. J. Zool., 42: 259-279.

3. Burri P. H., Gehr P., M üller K. \& Weibel E. R., 1975: Adaptation of the growing lung to altered oxygen requirements of organism. Effect of IDPN-induced hyperactivity in mice. I. Physiology. In preparation.

4. Dehnel A., 1950: Studies on the genus Neomys Kaup. Annls Univ. M. Curie-Skłodowska, C. 5: 1-63.

5. Dryden G. I., Ba umann T. R., Conaway C. H. \& Anderson R. R., 1969: Thyroid hormone secretion rate and biological half-life ( $t_{1} / 2$ of L-Thyroxine ${ }^{131} \mathrm{I}$ in the Musk Shrews (Suncus murinus). Comp. Endocrin. 12: 536-540.

6. Dryden G. L., Gębczyński M. \& Douglas E. L., 1974: Oxygen consumption by nursling and adult musk shrews. Acta theriol., 19, 30: 453-461.

7. Gębczyński M., 1965: Seasonal and age change in metabolism and activity of Sorex araneus L in n a e s, 1758. Acta theriol., 10: 303-331.

8. Gębczyński M., 1971: The rate of metabolism of the lesser shrew. Acta theriol., 16: 329-339.

9. Gębczyńska Z. \& Gębczyński M., 1965: Oxygen consumption in two species of water-shrews. Acta theriol., 10: 209-214.

10. Hawkins A. E., Jewell P. A. \& Tomlins on G., 1960: The metabolism of some British shrews. Proc. zool. Soc., London, 135: 99-103.

11. Hildwein G., 1972: Metabolisme énergétique de quelques mammifères et oiseaux de la forêt équatoriale. II. Résultats expérimentaux et discussion. Arch. Sc. Physiol., 26: 387-400.

12. Heim de Bals a c H., 1958: La réserve naturelle intégrale du Mont Nimba. XIV. Mammifères insectivores. Mémoires de l'IFAN, Dakar: 301-337.

13. Heim de Bals a c H., 1968: Recherches sur la faune des Soricidae de l'Ouest africain (du Ghana au Sénégal). Mammalia, 32: 379-418.

14. He i m de Bals a c H. \& A ellen V., 1958: Les Soricidae de basse Côte d'Ivoire. Rev. suisse Zool., 65: 921-956.

15. Heim de Balsac H. \& Barloy J. -J., 1966: Révision des Crocidures du Groupe flavescens-occidentalis-manni. Mammalia, 30: 601-633.

16. Hunkeler C. \& Hunkeler P., 1970: Besoins énergétiques de quelques Crocidures (Insectivores) de Côte d'Ivoire. La Terre et la Vie, 24: 449-456.

17. Kleiber M., 1967: Der Energiehaushalt von Mensch und Haustier, Parey, Hamburg und Berlin.

18. Malzahn E., 1974: Tissue metabolism in the common shrew and the bank vole. Acta theriol., 19: 301-314.

19. Martinsen D., 1969: Energetics and activity pattern of short-tailed shrews (Blarina) on restricted diet. Ecology, 50: 505-510.

20. Morrison P. R. \& Pearson O. P., 1946: The metabolism of a very small mammal. Science, 104: 287-289.

21. M orris on P. R., R y ser A. \& Dawe A. R., 1959: Studies on the physiology of the masked shrew Sorex cinereus. Physiol. Zool., 32: 256-271.

22. Nevo E. \& Shkolnik A., 1974: Adaptive metabolic variation of chromosome forms in mole rats, Spalax. Experientia, 30: 724-726. 
23. Pears on O. P., 1948: Metabolism of small mammals, with remarks on the lower limit of mammalian size. Science, 108: 44.

24. Poczopko P., 1971: Metabolic levels in adult homeotherms. Acta theriol., 16: $1-21$.

25. Repenning C. A., 1967: Subfamilies and genera of the Soricidae. Geological Survey Professional Paper, 565: 1-74.

26. Scholander P. F., 1955: Evolution of climatic adaptation in homeotherms. Evolution, 9: 15-25.

27. Tupikova N. W., 1949: Pitanie i harakter sutočnoi aktivnosti zemleroek sredniej polosy SSSR. Zool. Ž., 28: $561-671$.

28. Vogel P., 1970: Biologische Beobachtungen an Etruskerspitzmäusen (Suncus etruscus S a vi, 1822). Z. Säugetierkde 35: 173-185.

29. Vogel P., 1972: Beitrag zur Fortpflanzungsbiologie der Gattungen Sorex, Neomys und Crocidura (Soricidae). Verhandl. Naturf. Ges. Basel, 82: 165-192.

30. Vogel P., 1974: Kälteresistenz und reversible Hypothermie der Etruskerspitzmaus (Suncus etruscus, Soricidae, Insectivora). Z. Säugetierkde, 39: 78-88.

31. Weibel E. R., Burri P. H. \& Cla assen H., 1971: The gas exchange apparatus of the smallest mammal: Suncus etruscus. Experientia, 27: 724.

32. Wolk E., 1974: Variation in hematological parameters of shrews. Acta theriol., 19: $315-346$.

Accepted, Sept. 12, 1975.

Peter VOGEL

\section{ZAPOTRZEBOWANIE ENERGETYCZNE EUROPEJSKICH I AFRYKAŃSKICH RYJÓWEK}

\section{Streszczenie}

Próbując odpowiedzieć na pytanie czy poziom metabolizmu ryjówek jest rzeczywiście niezwykle wysoki, zmierzono zużycie tlenu u 13 różnych gatunków. Z gatunków europejskich były to: Sorex araneus, S. minutus, Neomys fodiens, Crocidura russula i Suncus etruscus; z afrykańskich - Crocidura bottegi, C. bicolor, C. jouvenetae, C. poensis, C. theresae, C. wimmeri, C. flavescens i C. giffardi. Pomiary wykonywane były przez 20-30 minut, w małym respirometrze typu zamkniętego, przy $25^{\circ} \mathrm{C}$. Poziom metabolizmu ryjówek z podrodziny Soricinae mieści się pomiędzy średnią a minimalną wartością właściwą Soricini $\left(M=126,2 W^{0.52} \mathrm{cal} / \mathrm{h}\right.$ i $M=82.6 W^{0.53} \mathrm{cal} /$ /h, odpowiednio), podawaną w literaturze (Tabela 1). Wartość średnia cechująca afrykańskie Crocidurinae jest znacznie niższa $\left(M=43.6 W^{0.67}\right)$ (Ryc. 1$)$.

Poziom metabolizmu europejskiej Crocidura russula jest taki jak u gatunków afrykańskich. Zatem Crocidurinae mają względnie niski metabolizm; Soricinae, a szczególnie tryb Soricini - bardzo wysoki. Tryby Neomyini i Blarinini zajmują pozycję pośrednią (Rys. 2). Różnice te dotyczą także metabolizmu podstawowego.

Ta wyraźna różnica pomiędzy oboma podrodzinami może być zapewne tłumaczona tym, że ewolucja przebiegająca przy izolacji geograficznej, w różnych warunkach klimatycznych, dostosowała Crocidurinae do tropikalnej Afryki a Soricinae do klimatu umiarkowanego Eurazji. 